\title{
Tabib Family's Role on Fracture Treatment in Aceh, 1950-2020: A Historical Reconstruction
}

\author{
Teuku Kusnafizal', Abdul Azis, Sufandi Iswanto \\ Study Program of History Education, Faculty of Teacher Training, \\ Universitas Syiah Kuala, Banda Aceh, Aceh \\ *Corresponding Author: kusnafizal@unsyiah.ac.id \\ DOI: https://doi.org/10.14710/ihis.v4i2.9497
}

\begin{abstract}
This research traces the origin of traditional fracture treatment, and identifies the values of local wisdom, especially in traditional healing process performed by the tabib family and to describe how the traditional healing system is developed from ancient times to the present. This study used a qualitative approach and historical

Received:

November 24, 2020

Revised:

November 30, 2020

Accepted:

December 7, 2020 methods through topic selection, heuristics or collecting sources, verification or source criticism, and sources and historiography interpretation. Based on the research that has been conducted, the following results were obtained: (1) Fracture treatment has been performed since 1950 in Aceh, especially among the tabib family coming from South Aceh through the inheritance of knowledge from generation to generation; (2) The regeneration process was performed in the healer family, in this case the father inherited from his children or grandparents to his grandchildren to study this knowledge, and practiced it in their entire life; (3) Entering the modern era, traditional medicine has developed in several aspects, so, people tend to believe in this treatment. This study is a part of the historical local wisdom (HLW) to determine how the development of traditional medicine in Aceh from time to time.
\end{abstract}

Keywords: Historical Reconstruction; Local Wisdom; Traditional Medicine for Fractures.

\section{Introduction}

Health is the right of every single person's life. It is especially attached to humans in general. According to Law No. 36 of 2009, Health is a state of health, both physically, mentally, spiritually and socially which allows everyone to live socially and economically productive. Health is the main asset for someone to do all activities. If someone is not healthy, with all the limitations, it is impossible to do that activities. One of the most common methods taken by a person when he/she is unwell (sick) is medication, both modern and traditional. According to Sarajar (1995, p. 2), traditional medicine is a health effort in a different way from medical science, rooted in original traditions or outside Indonesia. Only about $20 \%$ of diseases that can be treated through modern medicine, the rest is unknown for its cure, that's why traditional medicine is back into everyone's choice for treatment (Daniel, 2009, p. 9).

Law No. 36 of 2009 on health, recognizes the existence of tabib and traditional medicine as an indispensable part of health services. Traditional medicine is known to 
the public for centuries, long before the existence of modern medicine. This circumstance is supported by Indonesian circumstance which has a lot of flora and fauna that can be used as a medical tool in the past and until today. According to the Decree of the Minister of Health (Menkes) No. 176 of 2003, traditional medicine is classified into four groups: Battra Ramuan, Battra Keterampilan, Battra Supranatural and Battra based on a religious approach. Traditional medicine skills consist of traditional massage, fractures, circumcision, shaman, reflexology, acupressurist, acupuncturist, chiropractor and other traditional medicine with similar methods.

Traditional medicine for fracture skills is a form of treatment that is still believed by sufferers as an alternative to the treatment methods provided by medical science. According to Mangunsudirdjo (Fitri, 2018, p. 4), general goal of handling fractures is to seek bone healing without medical surgery, meaning that it is in a position where there are no functional abnormalities, and it will recover if adequate repositioning and adequate fixation are conducted, in general. The treatment method provides a reposition by massaging and fixing it with cardboard or wood. The traditional medicine system that develops in each society is different. It depends on belief, culture, and social life adopted by the communities. For example, in the life of Aceh people, it is always related to their social and cultural lives which are motivated by their life in the past. The traditional treatment for fractures is not something new for the communities, especially those in South Aceh. This traditional medicine is the main choice for people when they experience injuries or fractures even modern medicine is very advanced than traditional medicine at this time and modern medicine is used as an additional treatment. In addition, the more advanced modern medicine is, according to some people the costs will be more expensive when compared to traditional medicine and there are also people who think that traditional medicine is more effective and efficient than medical treatment, especially at Tabib Wen, which has long been known for fracture category (Nasrullah, Interview 2019).

Studies on fractures were conducted by Tedjodiprono (1982), Sarajar (1995), Aji et al. (2016), Siswanto (2018), Lesmana (2018) and Notosiswoyo (2001). Fractures are categorized into two parts, those are closed-fracture if there is no tear on the skin and open-fracture which is marked by injuries caused by fractures or certain objects that have torn the skin. Leonita (2015) and Indarto (2018), suggest that traditional medicine is an integral part of culture, because the concept of how to treat it is performed by reading several verses of the Koran and the presence of special ingredients. In traditional medicine, there are certain mechanisms and conditions that must be obeyed, so that it is a characteristic of the culture of the community concerned.

According to research conducted by Afriza (2017), traditional medicine is part of physical anthropology and it is related to biology, usually researcher uses a phenomenological theory approach to explain the data obtained on the field data. This disease is seen as a complex phenomenon that affects human life, so, traditional medicine appears as an alternative to treat patients who have had fracture accidents. The procedure for traditional treatment of broken bones are by conducting massage or hand healing methods and medicines derived from spices of leaves and roots of trees. 
It is relevant to Zubir's research (2019), stating that, the initial sheet of traditional medicine in the archipelago occurs since humans rely on the environment to meet their needs. In prehistoric times, human habits depended on nature and it could be seen from the way of gathering food, looking for shelter, relying on clothes from bark or animals including looking for drugs. The development of traditional medicine occurs during the time of Islamic kingdom in Indonesia, the kings in Indonesia advices the rishis or tabib to make potions and treat people with fractured injuries. The ingredients are Sikilia leaves, Merensi leaves, Selaguri leaves, Light leaves, and Rintang leaves, these are some of the medicines used by tabib to treat patients with fractures.

This research was conducted on December 8, 2019 to August 22, 2020, the research location was in South Aceh. The object was, the first, the role of tabib family in the treatment of fractures. The second object, was patients who visited the traditional fracture site. Then this research was using a case study of the tabib family, this is because the tabib family has long been practicing in South Aceh, the information stated that the first traditional treatment for fractures in South Aceh was Tabib Wen in 1950. Then after he passed away, the science of fracture medicine was passed on to his six children, one of them, namely Tabib Ali. The practice was seen every day. This was the number of people who believed in the traditional treatment of fractures. According to Lesmana, (2018) the term tabib referred to a person who conducted traditional medicine in several areas. In addition, in some areas the term tabib was the same as batra, shaman and masseuse.

\section{Method}

The research used a qualitative approach, where the researcher collected data by means of documentation, observation and interviews, so, they revealed problems according to the research needs. A qualitative approach was potentially interpreted as a research method based on the philosophy of post-positivism, used to examine natural object conditions, inductive, qualitative data analysis and qualitative research results to emphasize meaning rather than generalization (Sugiono, 2010, p. 14). The qualitative approach was also a research approach to understand the phenomena that was experienced by research subjects such as behavior, perception, motivation, action and others (Maleong, 2007, p. 6).

The method used was historical method as proposed by (Kuntowijoyo, 1995, p. 89), namely: topic selection, heuristics, or collecting sources, verification or source criticism, interpretation of sources and historiography or rewriting of historical events. In addition, the source of information in this writing was also obtained from the results of interviews, the first party to be interviewed was the family of 6 tabib and the second party was 12 patients. This study aimed to examine the history of fracture traditional medicine in Aceh. According to Garragahan (Abdurrahman, 1999, p. 43) the historical method is a set of systematic rules and principles for collecting historical sources effectively, critically, and systematically by evaluating the results in written form.

\section{The Origin of Fractures Traditional Medicine in Aceh}


Each treatment has a background story on how the origin occurs, for example, the descendants of a family. This family is known as the family of tabib. The word tabib is assigned to this family because they are able to heal fractures from the past generation to the current generation. This ability does not automatically arise in this tabib family, but it is rooted in something that happened. Attempts to transfer fracture treatment in this family are passed down to the next generation. Viewed from the perspective of philosophy, medicine is the initial science in society, this science exists because the guidance of life in society to find solutions on what happened in society. Science develops alongside the religion, so, it is interrelated with one another. It seems that in ancient times, humans use many rituals and spells to achieve their desired goals. The early developing knowledge is closely related to: prayer, mantra, and medicinal herbs, so, the earliest knowledge is medicine (Wijaya, 2006, p. 174).

The public's belief in fracture healers (tabib) is motivated by a tabib who is very skilled in fixing fractures named Abdurrahman. In 1950, marked by the birth of Tabib Aji, Abdurrahman had opened his own practice at Rumoh Tengoh to be precise in Ujong Blang village, Beutong District. Abdurrahman is known by the public as Tabib Wen. The tabib's call is assigned to him because he is able to conduct fracture fixing (sequences), and the word Wen means a boy taken from the Gayo language. Tabib Wen is the only child of Tabib Musa, someone who inherits his medicine. He is a person who plays a very important role in passing on this knowledge to his six children and grandchildren to his generation today. Tabib Wen obtains his knowledge from his father named Tabib Musa. Musa is born into the world with a physical condition that is less than perfect as he should be. He is not able to walk like ordinary people. With his circumstance, he is unable to work or help people. When he is an adult, his father, Tengku Sida, gives traditional medicine to help people who experience pain, especially fractures. Tengku Sida teaches Tabib Musa, starting from the prayers when performing medication or what is called "rajah" and introducing the anatomical location of bones to treat people with fractures. Rajah and massage are inseparable, both of them are united during treatment. When the broken bones are connected again in sequence, a rajah is conducted to make it more effective.

According to Notosiswoyo (2001), fracture shamans also obtain their skills in various ways, some are coming from whispers through dreams, whispers while in between sleeping and waking, given charms and prayers by their parents, and obtain expertise by apprenticeship at an older broken teacher/shaman. As explained by Notosiswoyo, it turns out that Tabib Wen did not only learn from his parents, especially in 1962 when Tabib Musa passed away, at that time people came to the Tengoh House for treatment, because he was the only child who was able to perform this treatment. Besides being taught by his father, Tabib Wen also dreamt of how the anatomy of human bones was located, so, when Tabib Wen woke up from his sleep, when he was performing the massage, he immediately felt and understood where the fracture was without an X-ray at that time (interview with Tabib Suh). Basically, this knowledge is in this family from generation to generation which is continuously being taught. So, it will never be broken until today. It comes from Allah, who is entrusted 
to their family, as they believed, they should not feel arrogant on the knowledge they have.

\section{Bone Fracture Treatment Development Process in Aceh}

The time is growing, but traditional medicine still exists in modern time. Many factors affect the popularity of traditional medicine such as the famous tabib, who treats many broken patients, the used drugs can be found in nature, so, the cost is relatively cheap, there are no worse decision happening such as having to have amputations and others. As explained in previous books such as Tajul Muluk, in general, the methods and medicines used are sipatah leaves, these leaves are usually used to heal fractures, in other words, these leaves are broken bones leaves, cool leaves, taro leaves, white grass, pulut rice and several other ingredients. The materials are crushed and placed on the broken part. However, this family is slightly different from what is described in the Tajul Muluk book. The used methods and medicines are formulated by this family, which is immediately evident from the inequality of drug concoctions between this family and other tabib.

In the early 1950, Tabib Wen opened his own practice at Rumoh Tengoh, as he tried to live independently from his father, Tabib Musa, until 2020, this treatment has been continued until generations of children, grandchildren, and even some of his great-grandchildren were able to treat this fracture. In the period between 1950 and 2020, it is a long time span, 70 years have passed, and this family of tabib still maintains their family heritage in the form of traditional medicine in the field of fractures and has its own ingredients and methods for treating fractures. As the years passed, there are many events that cause a new culture to enter the social order, so, this traditional medicine does not look rigid or outdate, this family finally adjusts the current developments with their knowledge. It can be seen that after the 2004 Tsunami in Aceh, many new medical devices emerged among the Acehnese people, such as scanning tools for several scan functions, including detection on break location. Public hospitals usually perform iron insertion operations (pins) to lock the broken bones so, they are straight and stick to both surfaces, the broken leg is replaced with an iron leg, and some even have to amputate the legs. The development of certified medical devices also adds the confidence of community by choosing this route, but many still choose traditional medicine in the healing process.

There are 20 patients visiting for treatment every week, and 80 people each month, the number of patients is like a hospital or community health center. All patients with fractures of various kinds are brought to this place, even, according to the story, there are some patients who pass away when they arrive there. However, the times develops and human thinking also increases. By the existing of medical facilities, patients are not immediately taken for treatment at this time, but they will be checked at the hospital first, have their wounds cleaned, and scan the broken parts. The hospital will usually provide several options for patient treatment. However, if the patient chooses to go home and seek treatment in traditional medicine, the hospital allows it. Afterward, the patient is brought to the place of broken healer (tabib) in several 
districts in Aceh. What is different in the field of medicine is the way patients are being treated, it appears that the public trust is fully given to tabib who treats him. However, at this time, to make the results more reliable, firstly is scan, then the results of the scan are submitted to the tabib to see what occurs to the bones.

Day by day, new discoveries in the medical field are increasing, but traditional medicine is still running. This is supported by control from the health office. Based on an interview with the Health Office (Dinkes), the medical service division explains that:

"...The health government of the South Aceh region has recorded the number of traditional healing practice locations for fractures. The number of treatment places according to the data is 12 practice locations. Furthermore, training will be held and certification will be given to each tabib at the place of treatment, so, the place of treatment is considered legal. For the government, this traditional medicine is very important and became the general public believe. Therefore, the Health Office (Dinkes) fully supports the smooth running and healing of the community. Until today, there has been no reporting due to practice failure. Then, what needs to be known is that the origin of fracture treatment in South Aceh was conducted by Tabib Wen in 1950, and has been famous from ancient time to the present. Maybe, if he is still alive, he should have provided the training to teach people who want to learn fracture treatment..." (Interview, August 3, 2020).

Based on the statement above, it is clear that currently the trust between health offices, hospitals, health centers with fracture healers (tabib) has been established. This family majoring in the medical field proves that traditional medicine is still reliable in choosing this healing method. There are several systems that are practiced by this family in treating people who have fractures. To initiate healing treatment, a patient can carry the conditions for treatment, this is recommended for patients who have severe fractures. So, they must be treated directly in one of these family practices. These requirements are likened to, for example, every person who enters a certain institution to apply for a job, enroll in school, enroll in college, for example, requires certain conditions so, he/she can work or study at the agency, as well as requires entry requirements for the process. Healing goes faster. Each condition brings its own meaning, so, tabib keeps this inheritance without adding or subtracting any ingredients that have been prescribed previously, although some of these healers (tabib) say that there are those who do not agree with the implementation of this circumstance. The provision of conditions to a tabib is termed as "Peunejok", meaning that if the patient has provided these circumstances, the patient is part of the tabib's family. The difference is in the way of giving (peunejok) to the healer (tabib), in the past the existing conditions are arranged in a small tray, but now it rarely looks like that. Now these conditions are put in a container which is important since the conditions must be sufficient.

\section{Fractures Traditional Treatment Requirements}

This requirement is one of the efforts before the traditional fracture treatment is performed, by these conditions, the treatment will be performed by the tabib, absolutely this requirement is one of the ways that the treatment takes place in the traditional 
place. The conditions or guidelines that must be met by the patient and the patient's family are as follows.

(1) Gold (meuh), the patient can give gold in the amount according to the patient's ability, not limited to whatever is given. It is an object whose selling value never decreases, so, when having treatment, the requirement is gold. When the patient's family needs the help of a tabib, they can give it to them. If the patient recovers, the gold will be sold and used during Tabib Wen's birthday feast which is annually held to buy the needed equipment; (2) Knife [badêk] bone is like a knife, broken bones will be repaired like normal bones and it is as strong as a knife (blade); (3) White fabric is the status of the patients are considered as family, therefore, life and death are at their home while being treated, so, if that happens the tabib family will also help their family; (4) Betel/ Ranub the Acehnese cannot be separated from betel when gathered in one place. When the condition is given by the patient's family, the betel will be eaten together at that time. Betel is given in the form that the ingredients have not been put together, such as daffodil, lime, areca nut and the betel itself; (5) Money [peng], which is only in addition to a few people for alms to the healer (tabib) who treats them. The amount of money is not pegged. Money becomes a trend in granting this condition because some who are able to give money are not necessarily asked by the tabib but sincerity from the patient's family to give it or not willingly.

After the peunejok process is received, the tabib immediately makes a visit to sort out the patient. The visit time between patients varies, depends on when the tabib has the time to order. Usually, the healer (tabib) massages in the morning and evening, during the day the patient uses physical exercise and regular activities. Ordering is conducted according to the type of fracture experienced by the patient, for example: if the patient breaks in the middle of the bone, a wooden splint will be attached and tied with siren bark for several days and tabib will massage it slowly, if the fracture is in the joint, it will be conducted according to patients' comfort.

In performing the massage, the healer (tabib) only massages at a suitable location by adding a balm whose properties are to relieve muscle pain, sprains, aches and others. For this family, they use a balm with the Tiger Balm brand or people often call it Rimung Cap Balm. This balm is very popular in Beutong sub-district, because it is the balm that is always used when the tabib performs massage. During the massage, besides rubbing the balm on the part of the body, the healer (tabib) also uses prayers, according to one interview source some of them seek prayer itself with the information given but some are taught directly. The used prayers are coming from Koran for example Alfatihah, Al-Ikhlas, An-Nas, and prayers to glorify Allah, then they make dhikr while massaging, then ask for the blessings of the Prophet Muhammad PBUH through prayers to Him, and proceed to prayer in one's own language, by asking God for healing so, the patient can recover and be able to conduct God's commands such as prayer and others. Time does not change the prayers that are always read during treatment. As times have developed, this family still uses prayers that have been given to them from generation to generation. It is just a little different in the ingredients when massaging, during Tabib Wen's time, according to a patient at that time, he performs 
the massage by collecting crude oil, a coconut water that is not dried in the sun, but the crude oil is no longer used, because it is not available and also there is no one who produces it. The information from a patient whose hand is dislocated named Saidil Mudhahar states that:

“... I had sprains as a result of an accident while I was playing football, the treatment process was conducted by applying balm and wood oil, then massaged and it felt quite painful. However, the pain was gradually disappeared, then after being massaged, I put the nutmeg on my feet..." (Interview, July 18, 2020)

After massaging is complete, the patient makes his own concoctions. The potion is a hot round stone, burned in a fire and then placed on a fabric containing lingeng pagee leaves that have been pounded and flaked on top of fabric, then bandaged and the hot stone is rubbed on the part that has broken slowly until the water disappears and the stone feels hot again. For patients who only experience sprains, they will only be given pounded nutmeg which is then applied to the affected area and rested. Apart from these drugs, the patient must follow several restrictions which make the fracture worse, make the body itchy and the most important thing is not to come into contact with anything that is not his mahram while this treatment is taking place. Further, as you can see, this knowledge is passed on to the offspring only. However, as time goes on, one of Tabib Suh's patients named Nasir is also able to perform this treatment even though he is not as skilled as this tabib but because of his strong belief and the belief that Tabib Suh is given to him. He is able to perform this treatment even though he only does it when Tabib Suh himself asked for help. It seems that in this era development which is changing, human thinking also changes, although there are several traditions that must be preserved, but for one's ability to perform healing, it returns to that person's will and belief.

This family's ability to cure is well known by many people. If you look at some medical practices, there must be an attached pamphlet to indicate the place of medical practice, in contrast to this family, from Tabib Wen's spell until today, they think that putting up pamphlets is a form of joy in their knowledge, so, they have not put up practical pamphlets in front of the house and continue to accept patients every day and every time. After the patient is cured, the patient will be given dipeusijuk or powdered by offers in an annual way of Tabib Wen, all patients who recover, usually bring food that is placed in a container and then distributed to the orphans and people who present at that time as a sign of gratitude to Allah for the blessings given by Allah for his/her healing.

\section{Conclusion}

Expertise in performing traditional fracture treatment is hereditary. Starting from learning to cure self-taught by Tengku Sida around 1900 as the first generation whose initial goal is to help the communities until it develops into a practice place that is known to many people and used as a treatment house, especially broken bones. Until today, the broken healer family (tabib) has 4 generations. This regeneration process is passed on from father to child or grandfather to grandson. Each tabib receives and 
inherits knowledge in different ways, but basically the knowledge is the same, that is by curing people with broken bones. This knowledge will be introduced and taught when the child enters puberty, then the inheritance of knowledge will be continued if the child has an interest in learning. However, in the process itself, the inheritance is not forced. Traditional treatment for fractures is an effort to help people with fractures bones, this cure aims to heal and make it easier for people to return to their normal activities.

\section{References}

Abdurrahman, D. 1999. Metode penelitian sejarah. Jakarta: PT. Logos Wacana Ilmu.

Afriza, N. (2017). Penyembuh tradisional di Gampong Rawa Kecamatan Tanah Luas Kabupaten Aceh Utara. Aceh Anthropological Journal 1(1), 21-43. https://doi.org/10.29103/aaj.v1i1.358

Aji, S., Nasution, Z., \& Bernadheta, S. (2016). Mbeko Patah Tulang "Tradisi pengobatan patah tulang pada etnik Manggarai". Yogyakarta: PT Kanisius.

Daniel, J. B. (2009). Spiritual healing, Scientific validation of healing revolution. Healing Research. Volume 1 24(1), 43

Fitri, R., Oktiarni, D., \& Arso, D. D. (2018). Eksplorasi pengetahuan obat tradisional dalam perspektif hukum kekayaan intelektual di Bengkulu. Mimbar Hukum Fakultas Hukum Universitas Gadjah Mada, 30(2), 304. https://doi.org/10.22146/jmh.31021

Indarto, I., \& Kirwanto, A. (2018). Explorasi metode pengobatan tradisional oleh para pengobat tradisional di wilayah Karesidenan Surakarta. Interest: Jurnal Ilmu Kesehatan, 7(1), 75-86. https://doi.org/10.37341/interest.v7i1.76

Kuntowijoyo. 1995. Pengatar ilmu sejarah. Yogyakarta: Yayasan Bentang Budaya.

Leonita, E., \& Muliani, A. (2015). Penggunaan obat tradisional oleh penderita diabetes mellitus dan faktor-faktor yang berhubungan di wilayah kerja Puskesmas Rejosari Pekanbaru Tahun 2015. Jurnal Kesehatan Komunitas, 3(1), 47-52. https://doi.org/10.25311/keskom.vol3.iss1.101

Lesmana, H., Alfianur, A., Utami, P. A., Retnowati, Y., \& Darni, D. (2018).

Pengobatan tradisional pada masyarakat tidung kota Tarakan: Studi kualitatif

kearifan lokal bidang kesehatan. Medisains, 16(1), 31.

https://doi.org/10.30595/medisains.v16i1.2161

Maleong, L. 2007. Metodologi penelitian kualitatif. Bandung: Remaja Rosda Karya.

Notosiswoyo, M. 2001. Review penelitian pengobatan tradisional patah tulang. Media Litbang Kesehatan, 17-24.

http://www.litbang.kemkes.go.id:8080/handle/123456789/79802

Sarajar, Lumi, R. Massie, G. W. 1995. Pengobatan tradisional Sulawesi Utara. Jakarta: Departemen Pendidikan dan Kebudayaan.

Siswanto, S. (2018). Pengembangan kesehatan tradisional Indonesia: Konsep, Strategi dan Tantangan. Jurnal Penelitian dan Pengembangan Pelayanan Kesehatan, 1(1), 1731. https://doi.org/10.22435/jpppk.v1i1.429 
Sugiyono. 2010. Metode penelitian pendidikan (Pendekatan kuantitatif, kualitatif, dan RED). Bandung: CV Alfabeta.

Tedjodiprono. 1982. Penemuan baru Ilmu pengobatan tradisional modern dengan Teori Mesin dan Computer. Jakarta: C.V. Genep Jaya Baru.

Wijaya, C. A. (2006). Ilmu dan agama dalam perspektif filsafat ilmu oleh: Cuk Ananta Wijaya 1. FIlsafat, 40 (Ilmu dan Agama Dalam Perspektif Filsafat Ilmu), 174-188. Zubir, Z. (2019). Dukun patah tulang dan obatan tradisional di Nagari Koto Anau Kabupaten Solok Propinsi Sumatera Barat Tahun 1960-2012. Jurnal Historia 7(1) 7-18. http://dx.doi.org/10.24127/hj.v7i1.1819 